\title{
Vascular Regression
}

National Cancer Institute

\section{Source}

National Cancer Institute. Vascular Regression. NCI Thesaurus. Code C82966.

A finding indicating shrinkage of the tissue volume of the vascular structures. 